\title{
Excretion Study of Clomiphene in Human Urine. Evaluation of Endogenous Steroids Profile after Multiple Oral Doses
}

\section{Dayamín Martínez Brito, Rodny Montes de Oca Porto, * Margarita Teresa Correa Vidal, Roberto Socarrás Ojeda and Arístides Rosado Pérez.}

\author{
Instituto de Medicina del Deporte, Laboratorio Antidopin, Calle 100 y Aldabó, \\ CP 10800 Ciudad de la Habana, Cuba
}

\begin{abstract}
Os moduladores seletivos do receptor de estrógeno são classificados como substâncias proibidas pelo Comitê Olímpico Internacional e pela Agência Mundial Anti-doping e, estão banidas de acordo com a listagem de substâncias proibidas nos esportes. Clomifeno, (2-(4-(2-cloro-1,2-difeniletenil) fenóxi)- $N, N$-dietil-etanamina) é usado principalmente no tratamento contra a infertilidade porque age na indução da ovulação por estímulos diretos da atividade gonadotrópica. Citrato de clomifeno foi administrado por via oral (50 mg por dia, por um período de 5 dias) a uma mulher saudável, como tratamento contra a infertilidade. As amostras de urina foram coletadas na frequência de uma dose por semana. Um metabólito novo foi identificado por cromatografia gasosa acoplada à espectrometria de massas, além do hidróxi-clomifeno relatado previamente. Propôs-se a estrutura do novo metabólito como sendo o hidroximetoxiclomifeno. A monitoração deste metabólito foi investigada e o hidroxiclomifeno foi excretado da urina relativamente mais rápido do que o hidroximetoxiclomifeno. Mudanças significativas no perfil dos esteróides após doses múltiplas foram observadas e a principal variação observada foi na concentração absoluta e na razão dos estrogênios.
\end{abstract}

Selective estrogen receptor modulators are classified as prohibited substances according to the list of forbidden substances in sports by the International Olympic Committee and the World Anti-doping Agency. Clomiphene (2-(4-(2-chloro-1,2-diphenylethenyl)phenoxy)- $N, N$-diethylethanamine) is mainly used for the treatment of infertility because it acts inducing the ovulation by direct stimulations of gonadotropic activity. Clomiphene citrate ( $50 \mathrm{mg}$ per day for 5 days) was orally administered to one healthy female with infertility treatment. Urine samples were collected up to 1 week post-dose. A new metabolite using gas chromatography-mass spectrometry has been identified in addition to the hydroxyclomiphene previously reported. It has been proposed as hydroxymethoxyclomiphene. Monitorization of this metabolite have been proposed for doping control keeping in mind that the main metabolite hydroxyclomiphene is excreted relatively faster than hydroxymethoxyclomiphene from urine. On the other hand, significant changes on steroids profile after multiple doses were observed. The main variation was observed on absolute concentration of oestrogens and their ratios.

Keywords: clomiphene, gas chromatography-mass spectrometry, oestrogens, steroids profile, doping control

\section{Introduction}

Clomiphene (2-(4-(2-chloro-1,2-diphenylethenyl) phenoxy)- $N, N$-diethyl-ethanamine) is a triphenylethylene derivative distantly related to diethylstilbestrol. It acts as a selective estrogen receptor modulator (SERM), similar to tamoxifen and raloxifene. All three drugs are competitive inhibitors of estrogen binding to estrogen receptors and

*e-mail: rodnylad@yahoo.com have mixed agonist and antagonist activity depending upon the target tissue. ${ }^{1}$

Clomiphene is sold as a mixture of stereiomers (cis and trans) $z u$-clomiphene and $e n$-clomiphene being the first one an estrogenic agonist and the last one an estrogenic antagonist. ${ }^{2-4}$ It is generally used as a stimulant of ovarian function and it's listed as a doping substance on the World Anti-Doping Agency (WADA) Prohibited List due to its selective estrogen receptor modulator capabilities. ${ }^{5}$ Treatment of negative effects of anabolic androgenic steroid 
abuse (e.g., gynecomastia) as well as a negative feedback to testosterone metabolism causing an indirect enhancement of the serum testosterone concentration is the main reason for the ban of this substance. ${ }^{4,6,7}$

Excretion of several clomiphene metabolites and clomiphene itself has been described after in vivo and in vitro studies. Its metabolism follows reactions of $N$-hydroxylation, $N$-deethylation and $N$-methoxylation..$^{8-11}$ Its relationship with plasmatic and urinary level variations of 17-hydroxyprogesterone, testosterone and luteinizing hormone has been described too. ${ }^{12-14}$

The aim of this work was to carry out an excretion study of clomiphene in human urine with the purpose to detect and to identify some of not previously reported metabolites after a multiple oral administration dose of clomiphene citrate to healthy volunteer using gas chromatography-mass spectrometry. Also, changes on endogenous steroids profile that can be used to diagnose clomiphene consumption were evaluated.

\section{Experimental}

\section{Urine samples and drug administration}

Clomiphene citrate (50 mg/day for 5 days) was orally administrated to one healthy female with infertility treatment. Three blank urines were collected to establish the individual references ranges of the endogenous compounds studied. Urine samples were collected up to one week postdoses. The Sports Medicine Institute Ethics Committee approved the excretion study protocol.

\section{Chemicals}

Disodium hydrogen phosphate anhydrous and sodium dihydrogen phosphate monohydrate were purchase by Merck, Germany; potassium carbonate (Sigma- Aldrich, Germany); methanol purity 99.93\% (Sigma, Germany); tert-butil methyl eter, purity 99.8\% (Sigma, Germany). The solid phase extraction columns Detectabuse ${ }^{\mathrm{TM}}$ (divinylbenzene/styrene copolymer, $15 \mathrm{~mL}$ ) were purchase from Biochemical Diagnostics, New York, USA. Mercaptoethanol was obtained from Fluka (Busch, Switzerland) and $\beta$-glucuronidase enzyme from E. coli. $\mathrm{N}$-Methyl- $\mathrm{N}$-trimethylsilyl-tri-fluoroacetamide (MSTFA) and the ammonium iodide $\left(\mathrm{NH}_{4} \mathrm{I}\right)$ was purchase from SigmaAldrich (Steinheim, Germany). 17 $\alpha$-Methyltestosterone (internal standard) was purchase from Research Plus Bayonne, New York, USA. Testosterone, epitestosterone, androsterone, etiocholanolone, estrone, estriol and estradiol were purchase from Sigma, Germany.

\section{Urine samples preparation}

After addition of the internal standard (500 ng of $17 \alpha$-methyltestosterone) in $2,5 \mathrm{~mL}$ of urine were concentrate on a Detectabuse ${ }^{\mathrm{TM}}$ column, previously conditioned with $2 \mathrm{~mL}$ methanol and $2 \mathrm{~mL}$ deionized water. The column was washed with $2 \mathrm{~mL}$ of deionized water and the analytes were then eluted with $2 \mathrm{~mL}$ of methanol. After evaporation of the methanol under a stream of nitrogen at $40{ }^{\circ} \mathrm{C}$, the residue was taken up in $1 \mathrm{~mL}$ of sodium phosphate buffer $\left(\mathrm{pH} \mathrm{7,} 0.2 \mathrm{~mol} \mathrm{~L}^{-1}\right)$ and then hydrolysed with $30 \mu \mathrm{L}$ of $\beta$-glucuronidase enzyme from $E$. coli at $55^{\circ} \mathrm{C}$ for $1 \mathrm{~h}$. The hydrolysate was cooled to room temperature and $250 \mu \mathrm{L}$ of $5 \%$ potassium carbonate solution were added. The mixture was extracted with $5 \mathrm{~mL}$ of tert-butyl methyl ether on a shaker for $20 \mathrm{~min}$. The extracted sample was centrifuged for $10 \mathrm{~min}$ at $1232 \times \mathrm{g}$ and the discarded organic phase was then evaporated to dryness under nitrogen stream at $40{ }^{\circ} \mathrm{C}$. Before derivatization the samples were dried in desiccators for $1 \mathrm{~h}$. The dried residue was derivatized with $50 \mu \mathrm{L}$ of MSTFA-NH ${ }_{4}$-mercaptoethanol (1000:2:6 v/m/v), and then incubated for $30 \mathrm{~min}$ at $60^{\circ} \mathrm{C}$.

\section{Instrumentation}

Analysis were carried out using a Hewlett-Packard 6890 gas chromatography (Palo Alto, CA, USA) coupled with a 5973 quadrupole mass spectrometer detection system. Gas chromatography separation was achieved on a capillary column Ultra-1, length $17 \mathrm{~m}$, inside diameter $0.20 \mathrm{~mm}$ and film thickness $0.11 \mu \mathrm{m}$; operated with helium at a flow rate of $1 \mathrm{~mL} \mathrm{~min}^{-1}$ and temperature programming of $182{ }^{\circ} \mathrm{C}$ ramped at $3.5^{\circ} \mathrm{C} \mathrm{min}-1$ to $220{ }^{\circ} \mathrm{C}$, ramped at $5{ }^{\circ} \mathrm{C} \mathrm{min}{ }^{-1}$ to $235{ }^{\circ} \mathrm{C}$, then increased at $40{ }^{\circ} \mathrm{C} \mathrm{min}^{-1}$ to $310{ }^{\circ} \mathrm{C}$; then $310{ }^{\circ} \mathrm{C}$ held for $4 \mathrm{~min}$. Injections of $2 \mu \mathrm{L}$ were effected at $280^{\circ} \mathrm{C}$ in the split mode (split ratio $1: 10$ ). The transfer line was heated at $280{ }^{\circ} \mathrm{C}$ and the ion source temperature was $230{ }^{\circ} \mathrm{C}$. The acquisition mode was full scan. The $\mathrm{m} / \mathrm{z}$ range was from 45 to $800 \mathrm{Da}$ and the mass spectrometer was operated in the electron impact mode at $70 \mathrm{eV}$. Selective ion monitoring mode was used for steroids profile quantification (testosterone and epitestosterone $\mathrm{m} / \mathrm{z}$ 432; androsterone and etiocholanolone $\mathrm{m} / \mathrm{z} 434$; estrone $\mathrm{m} / \mathrm{z}$ 414; estradiol $\mathrm{m} / \mathrm{z}$ 416; estriol $\mathrm{m} / \mathrm{z}$ 504).

\section{Excretion profile}

Excretion profile of the clomiphene metabolites was obtained by area ratio between the main ion of each one $(\mathrm{m} / \mathrm{z}$ 86) and ion $\mathrm{m} / \mathrm{z}, 446$ corresponding to internal standard (17 $\alpha$-methyltestosterone). 


\section{Endogenous profile quantitation}

To evaluate the endogenous steroids profile a calibrator sample (testosterone, epitestosterone, androsterone, etiocholanolone, estradiol, estrone, estriol at 80, 20, 2000, $2000,50,50,50 \mathrm{ng} \mathrm{mL}^{-1}$ respectively) was used. Individual references ranges were established according to $\mathrm{X} \pm 2 \mathrm{SD}$ from blank urines of the same subject.

\section{Results and Discussion}

\section{Excretion study}

In this study, it was possible to identify two urinary metabolites of clomiphene including the already reported metabolite hydroxyclomiphene. ${ }^{4}$ In the total ion chromatogram (TIC) several peaks were found, which were not observed in negative control urine specimens used from the same subject. The structures assigned to these peaks were based on the fragmentation patterns observed, and also from the data previously reported for aromatase inhibitors metabolism. ${ }^{15}$ Several metabolites have been described in rats following a metabolic step of $N$-desethylation and $N$-oxidation. ${ }^{9}$

In this study, hydroxyclomiphene was identified as main metabolite. Molecular ion of the mono- $O$-TMS derivative are $m / z 493$ and $m / z 495$ for the chlorine isotopes being the ion $m / z, 86$ and $m / z, 100$; the $\alpha$ and $\beta$ cleavage to amine group respectively (Figure 1A). A new metabolite proposed as hydroxymethoxyclomiphene was identified using gas chromatography-mass spectrometry. It was proposed as a hydroxylated-methoxylated metabolite following previous reports about metabolism of tamoxifen, a related substance to clomiphene. ${ }^{16}$ Molecular ion in mass spectrum for this metabolite appears displaced $30 \mathrm{Da}$ respect to hydroxyclomiphene evidencing the possible introduction of a new methoxy group in the molecule. Molecular ion was found at $m / z$ 523/525 (clorine isotopes) and its spectrum present the correspondent $\alpha(\mathrm{m} / \mathrm{z}, 86)$ and $\beta(\mathrm{m} / \mathrm{z}, 100)$ cleavage to amine group (Figure 1B).

Hydroxyclomiphene (metabolite 1) was excreted in higher proportion in human urine but disappeared relatively faster than hydroxymethoxyclomiphene (metabolite 2). It reached its maximum excretion rate at $5^{\text {th }}$ day of the study meanwhile metabolite 2 reached its maximum excretion rate seven days after the beginning of the treatment. It could be detected easily until eleven days (Figure 2). At six day of concluding the treatment ( $11^{\text {th }}$ day of the study), its abundance was even greater than metabolite 1 (Figure 3). The proposed metabolite can be used for screening purpose
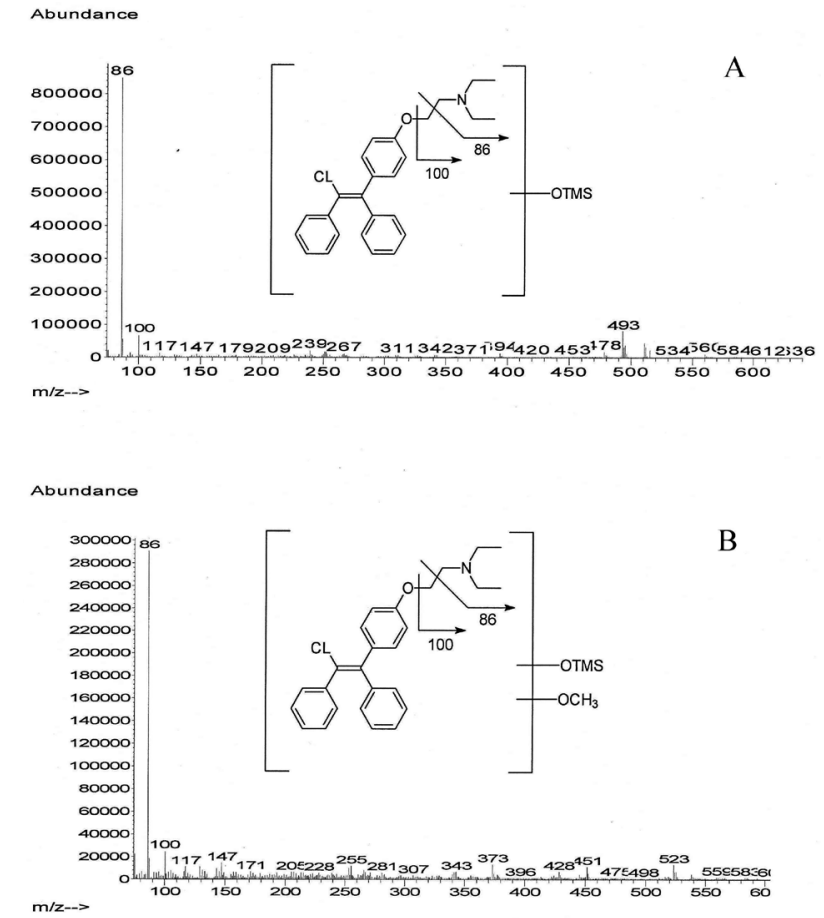

Figure 1. Mass spectra and chemical structure proposed for A: hydroxyclomiphene and B: hydroxymethoxyclomiphene $O$-trimethylsilyl derivative.

taking into account its long term excretion compared with metabolite $\mathbf{1}$ used for screening purpose by gas chromatography-mass spectrometry in most laboratories. For confirmation purpose it is recommended to use other techniques like liquid chromatography/mass spectrometry due it mass spectrum didn't show enough diagnostic ions with a relative abundance required by WADA.

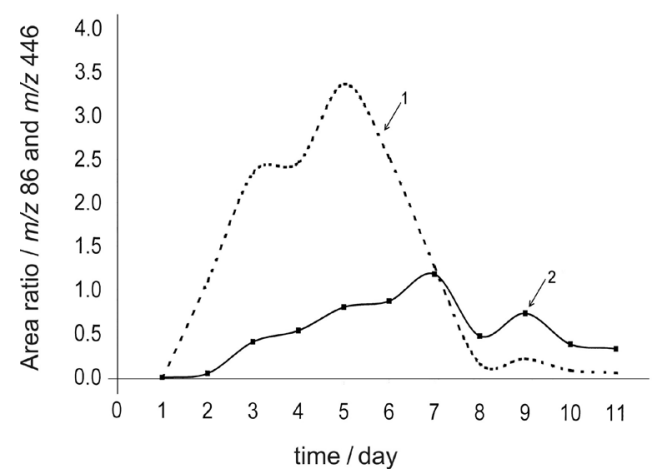

Figure 2. Excretion profiles of the two metabolites of clomiphene found in this study. --:hydroxyclomiphene (1) and $\mathbf{\square}$ : hydroxymethoxyclomiphene (2).

\section{Evaluation of the endogenous steroids profile}

After administration of multiple doses of clomiphene citrate variations on endogenous steroids profile were studied. The parameters evaluated were: testosterone (T), epitestosterone (E), androsterone (And), etiocholanolone 

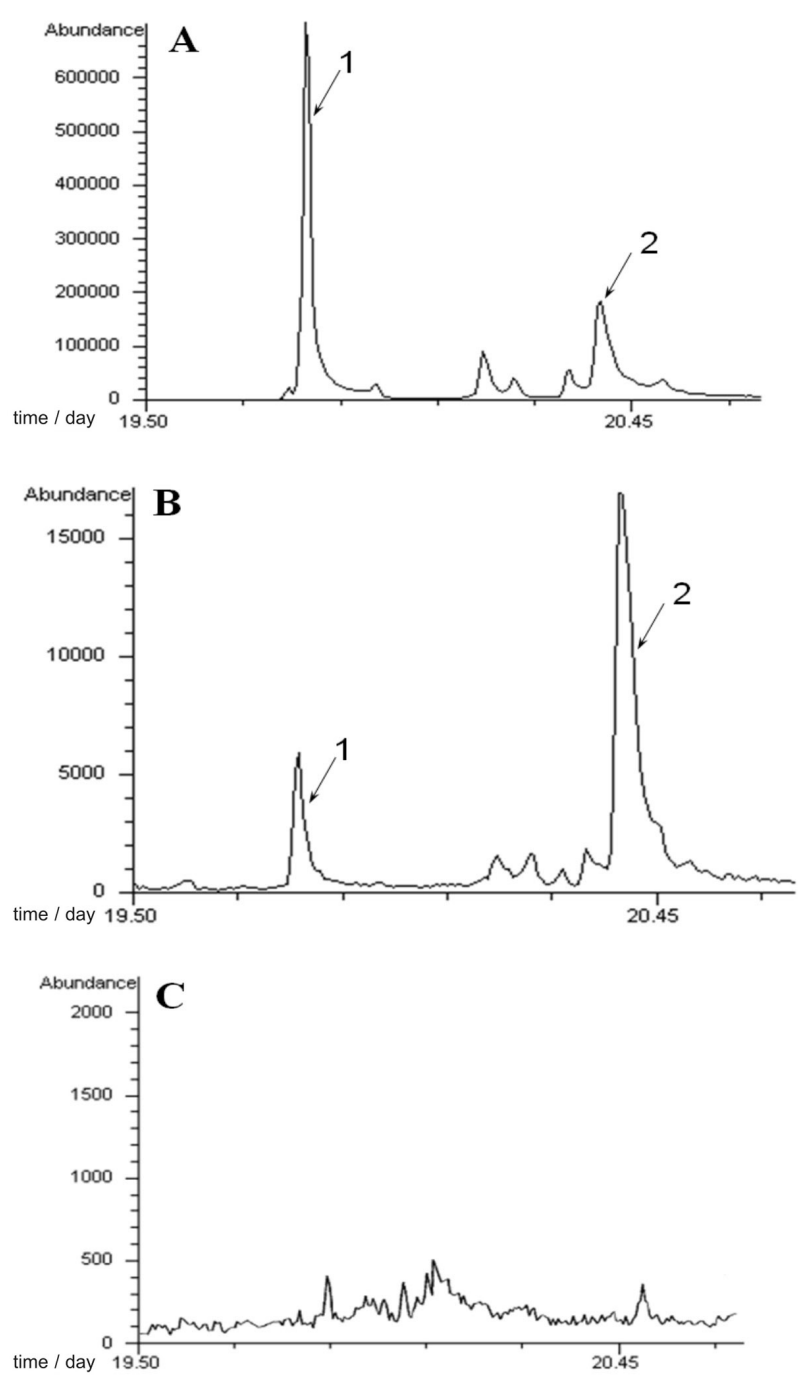

Figure 3. Ion chromatogram for $\mathrm{m} / \mathrm{z} 86$ at 5 days (A), 11 days (B) after beginning the treatment and blank urine before beginning the treatment (C). 1: hydroxyclomiphene; 2 : hydroxymethoxyclomiphene.
(Etio), estradiol, estriol, estrone and the area ratios $\mathrm{T} / \mathrm{E}$, And/Etio, T/estradiol, T/estriol, T/estrone, And/Lestrogens and Etio/乏estrogens. Individual references ranges are shown in Table 1.

After second day of drug administration, the principal variations on endogenous steroids profile were observed. Maximum and minimum values reached during the study are shown in Table 1. Absolute concentrations of T and $\mathrm{E}$ increased to values that exceeded the superior level of the individual reference range, meanwhile $\mathrm{T} / \mathrm{E}$ ratio showed a small decrease compared with the inferior level of the individual reference range established (Figure 4). This ratio remained stable from $3^{\text {rd }}$ day to the final of the study without significant differences. Absolute concentrations of And and Etio didn't show significant variations and their area ratio was the most stable parameter.

Most significant changes were observed in the estrogens. Absolute concentrations of estradiol, estrone and estriol showed increased levels compared to the individual references ranges until 14, 18 and 19 fold respectively, which is reflected in the high standard deviation. On the other hand, absolute concentrations of the three estrogens and their area ratios (T/estradiol, T/estrona, T/estriol, And/Eestrogens and Etio/ Eestrogens) showed significant variations. T/estradiol, T/estrone, T/estriol area ratios decreased 8, 6 and 12 fold respect to individual references values (Figure 5). And $/ \Sigma$ estrogens and Etio/ $/$ estrogens area ratios decreased 11 and 15 fold in respect to its initial values (Figure 6). These results demonstrate once again that inhibition in estrogen formation from testosterone cause activation in hypothalamus-hypophysis axis by negative feedback. As result, high estrogen production presumably by increase in FSH secretion was observed.

Table 1. Mean (X), standard deviation (SD) and individual references ranges from blank urine; $X$ and $\mathrm{SD}$ from samples during the study

\begin{tabular}{|c|c|c|c|c|c|}
\hline \multirow[b]{2}{*}{ Endogenous compound } & \multicolumn{3}{|c|}{ Negative samples data } & \multicolumn{2}{|c|}{ During study } \\
\hline & $\begin{array}{c}\mathrm{X} \\
\left(\mathrm{ng} \mathrm{mL} L^{-1}\right) \\
\end{array}$ & SD & $\begin{array}{c}\text { Excretion ranges } \\
\left(\mathrm{ng} \mathrm{mL}^{-1}\right)\end{array}$ & $\begin{array}{c}\mathrm{X} \\
\left(\mathrm{ng} \mathrm{mL^{-1 }}\right) \\
\end{array}$ & SD \\
\hline Testosterone & 6.8 & 1.3 & $4.2-9.4$ & 12.5 & 4.0 \\
\hline Epitestosterone & 4.3 & 1.5 & $1.3-7.2$ & 12.2 & 5.2 \\
\hline Androsterone & 2278.3 & 648.1 & $982.1-3574.5$ & 3400.3 & 801.5 \\
\hline Etiocholanolone & 1227.1 & 478.1 & $269.8-2184.4$ & 1604.9 & 374.9 \\
\hline Estradiol & 1.2 & 0.5 & $0.2-2.3$ & 7.1 & 5.1 \\
\hline Estriol & 3.9 & 1.3 & $1.4-6.4$ & 17.3 & 12.0 \\
\hline Estrone & 1.1 & 0.1 & $0.8-1.4$ & 7.7 & 7.9 \\
\hline $\mathrm{T} / \mathrm{E}$ ratio & 1.91 & 0.26 & $1.40-2.42$ & 1.26 & 0.34 \\
\hline And/Etio ratio & 1.29 & 0.15 & $1.00-1.59$ & 1.39 & 0.23 \\
\hline T/estradiol ratio & 10.83 & 2.40 & $6.02-15.64$ & 5.26 & 3.48 \\
\hline T/estriol ratio & 29.36 & 9.86 & $9.64-49.09$ & 2.58 & 1.34 \\
\hline T/estrona ratio & 4.24 & 0.46 & $3.32-5.17$ & 18.41 & 14.41 \\
\hline And// estrogens & 291.6 & 9.69 & $272.3-311.0$ & 155.0 & 101.8 \\
\hline Etio//2estrogens & 226.1 & 17.8 & $190.5-261.7$ & 116.0 & 89.1 \\
\hline
\end{tabular}

$\mathrm{X}=$ media $; \mathrm{SD}=$ standard deviation 

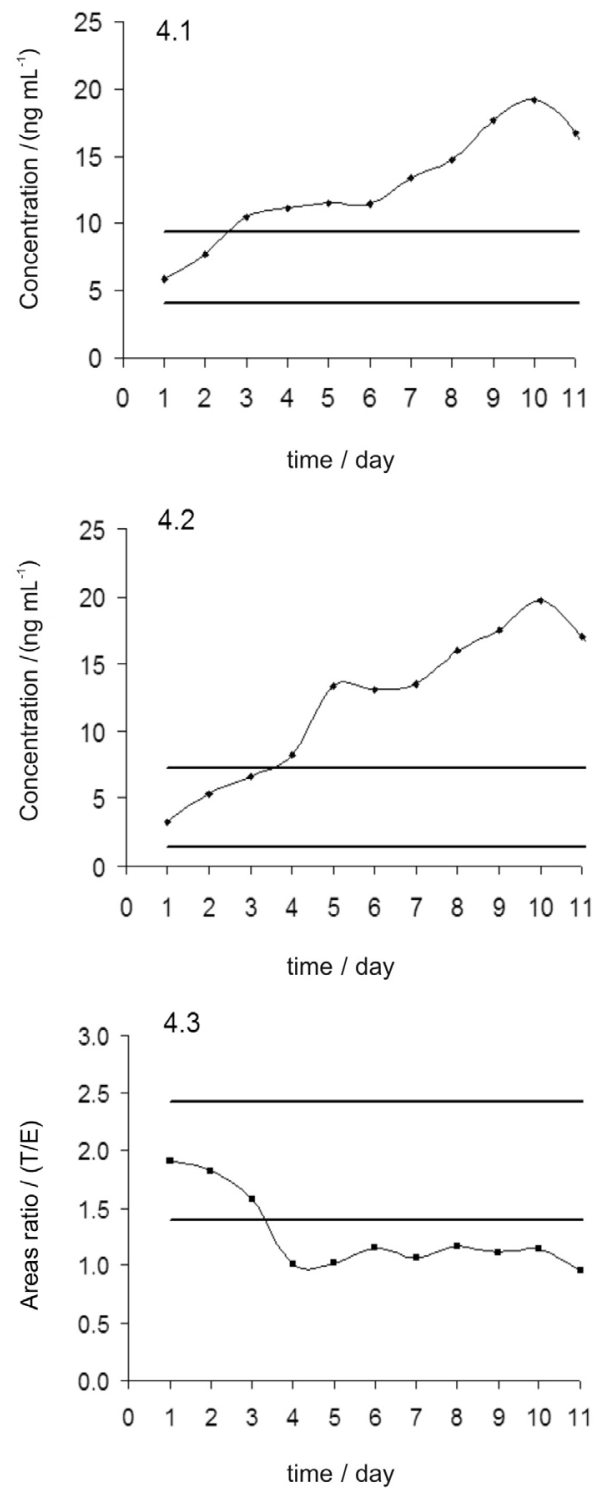

Figure 4. Absolute concentration of T (4.1), E (4.2) and T/E ratio (4.3) $v s$. time (day).

\section{Method validation}

In order to validate qualitatively the method to detect clomiphene consumption, selectivity/specificity, limit of detection (LOD), extraction recovery, repeatability (intraassay precision) and linearity were evaluated. ${ }^{17}$

Analysis of blank urine $(\mathrm{n}=10)$ and spiked blank urine samples with clomiphene proved that there is no interference from urine matrix in the determination of clomiphene. Intra-assay precision (repeatability), defined as relative standard deviation (\% RSD), was studied at two concentration levels (low at $50 \mathrm{ng} \mathrm{mL}^{-1}$ and high at $200 \mathrm{ng} \mathrm{mL}^{-1}$ ), with four replicates at each concentration level. The RSD was 5.4 and $3.6 \%$ for the low and high concentration levels, respectively.
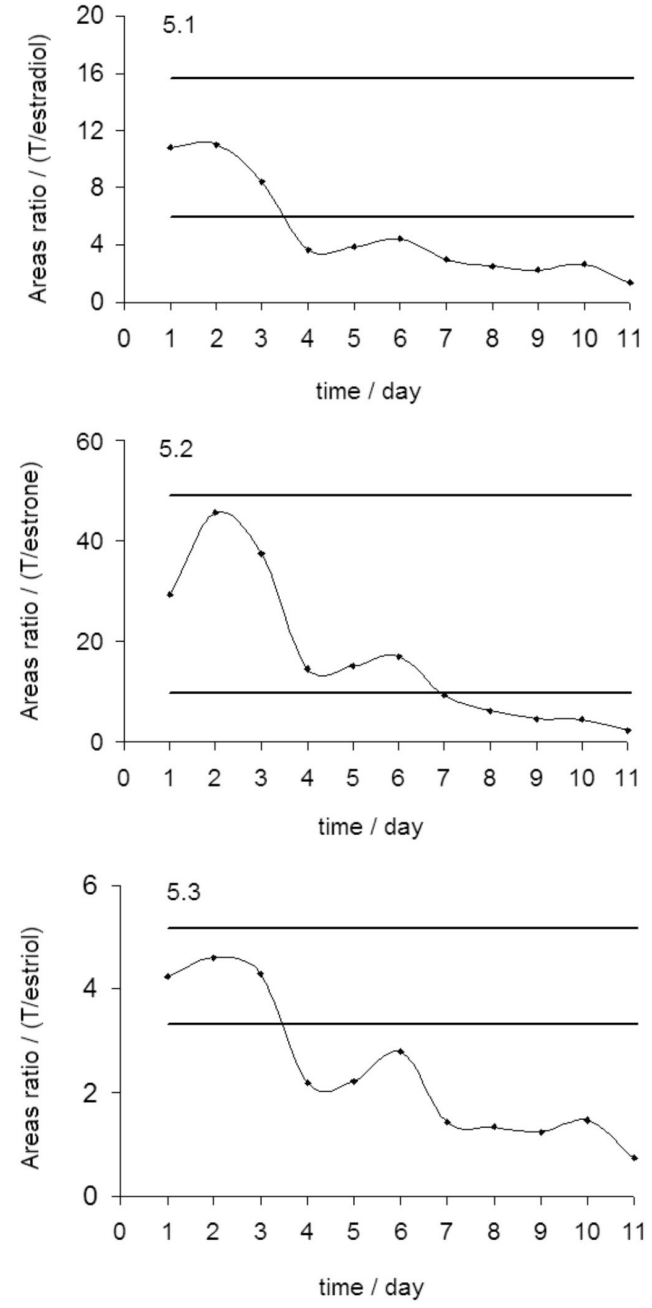

Figure 5. T/estradiol (5.1), T/estrone (5.2) and T/estriol (5.3) area ratios vs. time (day).

In order to calculate analytical recovery, relative areas of extracted urine samples were compared to relative areas of an unextracted solution of the same concentration. Analysis was carried out in four replicates at higher level quality control (200 ng mL $\mathrm{mL}^{-1}$ ). Clomiphene exhibited relative recovery of $89 \%$ (c.v. $3.6 \%$ ).

Limit of detection was evaluated by using decreasing concentration of clomiphene. The LOD was found at $25 \mathrm{ng} \mathrm{mL}^{-1}$ (signal to noise ratio $=12.3$ ), $50 \%$ less than the minimum required performance level established by WADA. ${ }^{18}$ Calibration curve was prepared by adding the compound $\left(25,50,100,150\right.$ and $\left.200 \mathrm{ng} \mathrm{mL}^{-1}\right)$ to a blank urine sample for triplicate, showing to be linear with a determination coefficient $r^{2}=0.9966$.

\section{Conclusions}

In this study it was possible to identify two urinary metabolites of clomiphene after multiple 


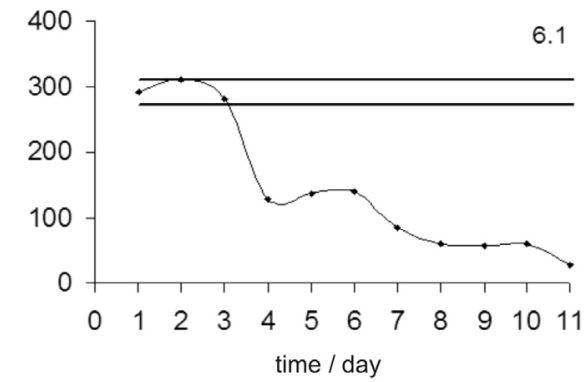

6.1

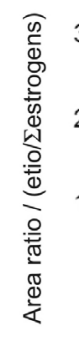

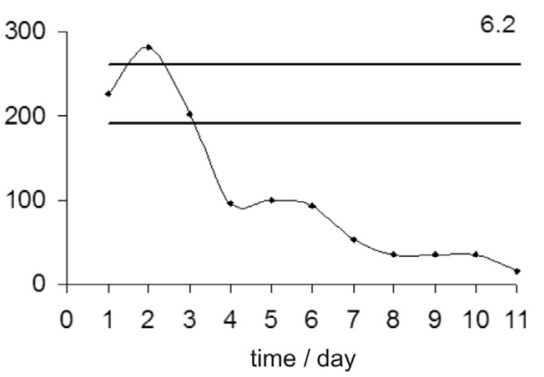

Figure 6. And/Lestrogens (6.1) and Etio/Lestrogens (6.2) area ratios $v s$. time (day).

oral administrations using gas chromatography-mass spectrometry. Hydroxyclomiphene, the main metabolite that is monitored for doping control disappeared relatively faster than hydroxymethoxyclomiphene from urine; therefore monitoring this additional proposed metabolite is recommended. Also, this study showed that after multiple doses of clomiphene citrate, And/Etio ratio and its absolute concentrations were the most stable parameters while T/E ratio decreased in the $3^{\text {rd }}$ day of treatment, remained very stable until the end of the study. Absolute concentration of the three estrogens evaluated showed a considerable increase. The ratios studied were modified too. T/estradiol, T/estrone, T/estriol, And/Lestrogens and Etio//Eestrogens area ratios showed notable variation and for this reason these ratios can be a useful tool to diagnose a clomiphene consumption. Also, the technique to detect clomiphene was successfully validated.

\section{References}

1. Shelly, W.; Draper, M. W.; Krishnan, V.; Wong M.; Jaffe, R. B.; Obstet. Gynecol. Surv. 2008, 63, 163.

2. Rostami-Hodjegnen, A.; Lennard, M. S.; Tucker, G. T.; Ledger, W. L.; Phil, D.; Fertil. Steril. 2004, 81, 1187.

3. Goldstein, S. R.; Siddhanti, S.; Ciaccia, A.V.; Plouffe, L.; Human Reprod. Update 2000, 6, 212.

4. John, A.; Linda, D.; Raja, W.; Toxicol. Appl. Pharmacol. 1972, 23, 339 .

5. WADA. The World Antidoping Code; International Standard for the Prohibited List.Available: http://www.wada-ama.org/ rtcontent/document/2009_List_En.pdf, accessed in May 2009.

6. Mareck-Engelke, U.; Sigmund, G.; Opfermann, G.; Gayer, H.; Schanzer, W.; Recent Adv. Doping Anal. 2001, 9, 53.

7. De Luis, D. A.; Aller, R.; Cuéllar, L. A.; Terroba, C.; Romero, E.; Ann. Med. Interna 2001, 18, 489.

8. Ruenitz, P.; Arrendale, R.; George, G.; Thompson, C.; Mockler, C.; Nanavati, N.; Cancer Res. 1987, 47, 4015.

9. Ruenitz, P.; Baggley, J.; Mockler, C.; Biochem. Pharmacol. 1983, 32, 2941.

10. Ruenitz, P.; Arrendale, R.; Schmidt, W.; Thompson, C.; Nanavati, N.; J. Med. Chem. 1989, 32, 192.

11. Ruenitz, P; Drug Metab. Dispos. 1981, 9, 456.

12. Tulay Kilic-Okman, T.; Kucuk, M.; Altaner, S.; Fertil. Steril. 2003, 80, 1330.

13. Miyake, A.; Yoshimoto, Y.; Hirota, K.; Wakimoto, H.; Terakawa, N.; Aono, T.; Tanizawa, O.; Eur. J. Obstet. Gynecol. Reprod. Biol. 1987, 26, 19.

14. Carlström, K.; Fredricsson, B.; Int. J. Androl. 1980, 3, 417.

15. Grobe, J.; Lang, R.; Mueller, R. K.; Thieme, D.; Recent $A d v$. Doping Anal. 1995, 2, 317.

16. Biteker, G.; Ugur, M.; Deber, R.; Fertil. Steril. 2004, 82, S145.

17. Jiménez, C.; Ventura, R.; Segura, J.; J. Chromatogr., B: Anal. Technol. Biomed. Life Sci. 2002, 767, 341.

18. WADA. TD2009MRPL, Minimum Required Performance Levels for Detection of Prohibited Substances. WADA technical document 2009, version 1.0. Available: http://www. wada-ama.org/rtcontent/document/MINIMUM_REQUIRED_ PERFORMANCE_LEVELS_TD_v1_0_January_2009.pdf, accessed in June 2009. 